\title{
Paideusis
}

\section{Autonomy and Schooling (Eamonn Callan)}

\section{Richard Barrett}

Volume 3, Number 2, 1990

URI: https://id.erudit.org/iderudit/1073401ar

DOI: https://doi.org/10.7202/1073401ar

See table of contents

Publisher(s)

Canadian Philosophy of Education Society

ISSN

0838-4517 (print)

1916-0348 (digital)

Explore this journal

Cite this review

Barrett, R. (1990). Review of [Autonomy and Schooling (Eamonn Callan)].

Paideusis, 3(2), 45-47. https://doi.org/10.7202/1073401ar

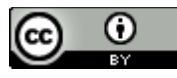

This document is protected by copyright law. Use of the services of Érudit (including reproduction) is subject to its terms and conditions, which can be viewed online.

https://apropos.erudit.org/en/users/policy-on-use/ 


\section{Book Review}

Eamonn Callan Autonomy and Schooling (Kingston and Montreal, McGill-Queen's University Press, 1988). 161 pages. Hardback: \$24.95

This book is a defense of a cluster of child-centered doctrines about education. The author begins by distancing himself from some discredited ideas associated with child-centred education, such as the natural goodness of children and the conception of education as a process of growth. He then proceeds to argue for a school curriculum based on students' psychological needs, for compulsion to a limited extent, and for a democratic authority structure in the later stages of schooling. These prescriptions are founded upon views about the nature and value of freedom and autonomy which are discussed, with little direct reference to education, in the opening chapters.

The discussion of freedom takes us by way of treating it as a means to an end, such as human happiness, or as of intrinsic value in its own right, to positing that it could instead be of value as constitutive of something of larger complexity which is of intrinsic value. This enables the conclusion that one kind of value that freedom has, is as constitutive of a life in which autonomy, or self-rule, can be exercised and flourish. This is similar to, but not quite the same as, saying that freedom is a necessary condition for the exercise of autonomy.

A notion of personal autonomy is worked out in which an autonomous person is one who regulates his or her will while displaying a high degree of realism and independence of mind. This is an ideal, which is only faintly reflected in some lives. Yet, the notion Callan elaborates is free of some perfectionist elements often associated with autonomy, such as a propensity to engage in endless criticism and ratiocination. Since the realism referred to here includes such things as the disciplined suppression of self-deception, autonomy is not easy to achieve or maintain.

The author argues that autonomy is intrinsically valuable, as well as being necessary to both the exercise of moral virtue and the achievement of justifiable self-respect. This is a strong conclusion, since it entails that we could not repudiate autonomy while retaining other things that are valuable or indispensable.

The chapters on freedom and autonomy are nicely argued. The significance of an understanding of the two concepts as a prerequisite to addressing a variety of morally important questions is well established--as it could have been by purely Kantian arguments. But there is also a welcome element of practicality or worldliness in the account of autonomy as central to life generally, not just to the life of the mind.

The most important chapter for Callan's argument is the one on interests and schooling. Here, it is argued that the school can enlarge freedom and promote autonomy by offering a curriculum that develops students' interests. The main thing at stake in practical terms is whether the pupil should be able to pursue a relatively specialised course of study at an early age. At a theoretical level, however, the author has to contend against other views on the importance of children's interests, such as that of J.P. White, whose education for autonomy stresses breadth of understanding and the development of a moral perspective. 
Callan shows skill in addressing the issues in the terms that his opponents have used in their works. But there is little gained by discussing in detail the arguments for making some subjects, but not others, compulsory, or the implications of the alleged lack of moral experts. And in the light of what is at stake in practice, it is curious that a writer in North America should be interested in the subject as construed by White and other British writers. For in England, the relatively early age for leaving school or continuing with a very narrow range of subjects (sixteen years) gives some point to what is called for by those who support breadth of understanding for all. In North America, where studies are pursued more broadly even in higher education, a different situation pertains. Callan believes that some are stifled by having to pursue liberal education too long before being able to specialise in a chosen field. But the plausibility of this depends too much on examples of people with certain rare types of ability, such as musical talent at the highest level, which is not clearly pertinent to the aims of education for all. And I wonder whether, on balance, the time wasted on liberal education, when it is a waste, is less than would be the time wasted on earlierchosen specialisation later regretted. Admittedly, Callan might have an answer to that--he makes a point of distinguishing his notion of autonomy from postreflective preference. But even so, one is reluctant to accept that choices to specialise during teenage years are more conductive to freedom and autonomy than choices made in a variegated curriculum that itself includes several electives.

The chapter on freedom and schooling is a defense of compulsory school. The argument is weak in some of its detail-such as in an attempt to distinguish compelling from coercing--but has as a strength an account of paternalism which unlike some other accounts in the literature is defensible to a liberallyminded person. The case for compulsion is less decisive for more mature people, hence fewer hours' compulsory attendance a week is recommended.

The final chapter on the government of schooling is devoted to showing that extensive student participation in school government is a reasonable policy under certain conditions which are not too difficult to realise; and, the nonrealisation of those conditions would show that the schools have failed in their educational objectives. The value of autonomy is the basis of the argument, and the schools, if not failing, will themselves have made at least the senior pupils ready for responsible participation in government. This is an ingenious argument which I am unable to fault. I hope it is published as an article in its own right; it should become a classic.

Let me conclude with some comments on the book as a whole, excluding the last chapter. The limitations of it are ones shared by other works in philosophy of education. Freedom is discussed without the complications that come from seeing a trade-off with other values, notably order and equality. The concept of autonomy is tempered with realism through a touch of intuitive good sense, rather than by reference to any of the extensive literature on bounded rationality, and is treated without recognition of any need for a trade-off with interdependence or fraternity. And perfectionist reasoning is still engaged in when opposing views are assessed in terms of whether they 'necessarily' or 'invariably' lead to something, which is not appropriate in education, or in human affairs generally. The scholarly preparation on autonomy and interests is fairly extensive--the index spills onto a second page--but the literature on child- 
centred education is not much referred to. The writing style is intelligent, but not at all literary or imaginative; I found the book quite a labour to read, even though it is on a subject I enjoy.

The merits of the book are in its contribution to some central topics in analytic philosophy of education. It advances the discussion of autonomy and related matters such as interests, and puts forward a distinctive point of view worked out with thoroughness. The repudiation of the position of some other philosophers, that children's interests are important only in the manner, not the matter, of schooling, deserves to be noticed.

Richard Barrett, Elmira College, Elmira, N.Y. 